\title{
The 12 Steps of Addiction Recovery Programs as an influence on leadership development: a personal narrative
}

DOI 10.1515/ijtr-2016-0009

received August 2016; accepted October 2016

\begin{abstract}
My participation in a 12-step addiction program based on the principles and traditions of Alcoholics Anonymous (AA) has been critical for my leadership development. As I worked to refrain from addictive behaviors and practiced 12-step principles, I experienced a shift from individualistic, self-centered leadership towards a servant leader orientation. I thus consider the 12-step recovery process, which commenced in 2001, a leadership formative experience (LFE) as it had the greatest influence on my subsequent development. My experience of thinking about and rethinking my life in reference to leadership and followership lends itself to a personal inquiry. It draws on work on the12 steps; self-assessments and personal journal entries; and memory of life events. I aim to contribute to the leadership development literature by exploring the influence of participation in a 12-step recovery program and posing it as an LFE, subjects that have received little attention.
\end{abstract}

Keywords: Leadership; Leadership development; Followership; 12-step recovery programs; Personal inquiry

\section{Introduction}

You can't stop a behavior. Nothing else is important. You're miserable. Your life is a shambles. You've admitted you're addicted and cannot recover alone. So you've decided to check out a 12-step program based on the principles and traditions of Alcoholic Anonymous (AA).

* Corresponding author: Mitchell Friedman, University of San Francisco, P. O. Box 460642, San Francisco, CA 94146-0642. Email: friedman@usfca.edu
I had arrived at the same realization when I attended my first 12-step meeting in June 2001. Now, over 15 years later, my life has changed for the better-as it has for others grappling with the pernicious consequences of addiction to behaviors (e.g., smoking marijuana, gambling, compulsive eating, viewing pornography) or who are friends, family, or children of addicts coping with their relative's behaviors. One day at a time, I strive to abstain from compulsive behaviors while applying 12-step program principles to my entire life. I'm more productive, engaged, and happier as a result.

Kaskutas et al. (2014) differentiate between two types of recovery. "Essential recovery" involves learning how to be honest with oneself, handle negative feelings, and being able to enjoy life. "Enriched recovery" refers to a process of growth and development, reacting to life's ups and downs in a more balanced way, and taking responsibility for the things one can change.

I've long reflected on my enriched recovery, specifically the influence of participation in a 12-step program on my professional life. Within this domain I've focused on how the principles and traditions of AA have shaped my leadership practice.

Over the last several years, I have pondered the relative importance of influences (e.g., parents, work, graduate study in leadership) on my leadership development. I've concluded that my recovery work has been the most significant. It fundamentally changed how I viewed myself as a leader and continues to shape related attitudes and behaviors. In other words, I consider my 12-step work to be a leadership formative experience without which I cannot imagine being leader I am today (Janson, Popper, Blyde, Markwick, \& Ranatunga, 2008).

Participation in an AA-related program has not been considered as an LFE, nor has leadership development in general been viewed through the lens of the 12-step addiction recovery program experience. How participation in a 12-step program based on the principles and traditions of AA has had consequences for leadership displayed by recovering addicts inside and outside the program, 
moreover, also has received limited attention (see Groves, 1972; Whiteside, 2013). My experiences in recovery over the last 15 years, presented in this personal inquiry, will address these topics.

\section{Methodology}

This article challenged me to reflect on my self and experience at different times in recovery while embracing my own subjectivity, emotionality, and influence on my research. In the process I've attempted to make 12-step work familiar to non-addicts, while melding personal narrative, traditional scholarly analysis, and connections to literature (Ellis, Adams, \& Bochner, 2011; emerald \& Carpenter, 2016). I draw on my work on each of the 12 steps; personal journals, leadership self-assessments completed as a doctoral student; and memory of life events. This effort enabled me to make meaning of my life from a new perspective.

While I'm anxious about making my 12-step experience known outside of program, I believe I'm at a point in my life when I must. To deny the influence of this work on my leadership development would leave my story incomplete and less than what I consider authentic. I feel vulnerable but am willing to risk it.

I've opted to limit the focus of this inquiry to the experience of being a member of a program based on AA's principles and traditions, without disclosing my specific addiction. I'm uncomfortable delving into these details. I feel such information could detract from more important messages I'm trying to communicate. I also respect AA's tradition of anonymity, which urges members not to identify as alcoholics outside the room (Alcoholics Anonymous World Services, Inc., 1981). I believe it supports my decision not to disclose participation in a specific 12-step program. That said, I speak for myself alone. I'm not a designated 12-step program representative nor do I reflect the official perspective of AA or other 12-step programs.

Finally, my reference to others' perspectives on my leadership development is intentionally absent. My focus is intrapersonal. I draw on self-knowledge, self-regulation, and self-concept to attempt to make sense of life experience. While I retreated into my inner self to write this piece I knew I was not working in a vacuum. I recognized that leadership consists of leaders and followers so I constantly subjected reflections to experiences in these roles (Northouse, 2016; Shamir \& Eilam, 2005; Sparrowe, 2005).

\section{Leadership Formative Experi- ences (LFEs)}

Janson et al. (2008) observed that LFEs had potential to advance individual learning about leadership by "encouraging reflection and discussion .... (and) further sense making of the experience for leadership development" (p. 20). The researchers attempted to shed light on inner reflective processes that contribute to the appraisal of certain types of experiences as formative. Those experiences were divided into categories: 'natural processes,' when a leadership role was assumed; coping and struggle, which included an element of adversity; self-improvement, when a challenge was present; some evidence of being partly driven by a cause; a significant relationship with (real or symbolic) parents; and the prominence of role models.

Study participants recalled self-improvement experiences first, although they were not necessarily viewed as formative when they occurred. Other findings suggest leadership learning material lay dormant within leaders and highlighted the potential for tapping into these experiences in ways not previously considered.

Bennis and Thomas (2002) describe the process of making meaning out of difficult events, like Janson et al. (2008). They refer to them as crucibles that inspire individuals to cultivate their own distinctive leadership voice. "The individual is transformed, changed, and created anew .... The crucible is a dividing line, a turning point, and those who have gone through it feel that they are different from the way they were before" (Bennis, \& Thomas, 2002, p. 104). Like with LFEs, the individual determines whether or not an experience is a crucible. Most come about through naturalistic and accidental events, and are not deliberately planned (Kempster, 2007).

The transformative quality of LFEs/crucibles resonates with my self-assessment of leadership development while participating in a 12-step addiction recovery program based on AA. The following narrative illustrates this point.

\section{What it was like as a leader before I entered recovery}

During the initial phase of my career (1980s-2000) I had never doubted that I was a leader given experiences as a public relations consultant, officer in professional organizations, and university instructor. In fact, it was part of 
my self-concept (Kouzes, 1998; Shamir \& Eilam, 2005). I believed I possessed leadership traits such as intelligence, determination, integrity, and sociability. I considered myself a trusted advisor, the individual clients turned to when an issue demanding immediate attention first arose (Maister, Green, \& Galford, 2000; Northouse, 2016).

In general, I was at this point a formal leader in title by virtue of my talents, energy, sociability, and hard work. I demonstrated skill in organizing groups of people for a common purpose, and a gift for connecting people with each other for their mutual benefit. I was learning to use the legitimate power vested in me by virtue of my roles, and was slowly developing my potential for referent power (Hughes, Ginnett, \& Curphy, 2006). I also was energized by what I believed I could achieve as an informal leader, a feeling magnified by the positive feedback I received from clients and peers.

Leadership was more about doing than being, however, and looking good was my paramount consideration. I used my intellectual and persuasive talents to this end. For example, I memorized Catholic Social Teaching while consulting with a faith-based organization. I recited it so passionately that some people believed I had converted to Catholicism. I basked in this positive attention.

My subsequent 12-step work also illuminated a profound unease with the world that fostered self-centered, rude, and inappropriate behavior during this period in my life. I did not understand emotions, and felt unable to regulate my own as a person more sensitive to emotional intelligence might attempt to do (Schutte, et al., 1998). I remained oblivious to my impact on others, moreover. I didn't care about other people beyond their role in completing a project. My goal was to complete a job quickly, well, and be recognized for it. From a more positive perspective, I was fully committed to being all I could be and making a difference (Shamir \& Eilam, 2005).

I also struggled to deal with supervisors who I felt oversaw my work too closely, were unforgiving of mistakes, and obsessed about seemingly unimportant details (White, 2010). More importantly, I believed they were less capable than me-and constantly wondered why didn't they recognize my superior talent.

In short, I felt my career and life had stagnated as I approached my $40^{\text {th }}$ birthday in 2000. I felt acutely alone and had very few people I could call friends. I was frustrated, depressed, bitter, and angry. I seemed to be in a consistently foul mood that adversely colored my interactions and decision-making (George, 2000). I generally felt lethargic and believed I would never to be able to pull myself out of rut I was in (Friedman, 2016).

I held dearly onto the belief that outcomes in my life were primarily the result of luck and fate, moreover. I consistently felt like a victim despite a belief in my superior intellect and good intentions (McShane \& Von Glinow, 2013). I felt powerless to change.

\section{What happened}

In short, I couldn't figure out what was wrong much less how to change it. Perhaps that realization allowed me to begin to grasp the magnitude of certain behaviors that had become central to my life during the late 1990s. They were increasingly compulsive, consuming, and demoralizing. Moreover, these behaviors threatened to upend the longterm relationship with my wife as she had grown tired of surly demeanor and emotional unavailability.

This growing realization led me to admit to myself I was an addict for the first time in late 2000. I struggled to cease my addictive behaviors until my wife confronted me on February 2, 2001. That's the day I first admitted I was an addict out loud. I felt a deep sense of relief, yet feared what would happen next.

I began attending meetings of a 12-step program based on the principles and traditions of AA a few months later. For the first two to three months I believed sharing the nature of my behaviors with others would suffice. It hadn't yet occurred to me that there was more to membership in a 12-step program than talking and listening. The 12-steps were intellectually appealing yet little more than that at this point. While I had ceased my addictive behaviors, I remained angry, negative, and critical of others.

Then I had what I later learned was a spiritual experience (Alcoholics Anonymous World Services, Inc., 2001, p. 567). As I listened to addicts speak at a Saturday morning meeting, I felt the power of a voice that no one else could hear. It cried out, "Mitchell, you need to work the steps." I didn't know whose voice it was. I didn’t even know what was involved in "working the steps." I recognized, however, that I was powerless over the addiction. I knew what I had to do. I would work the steps, not simply memorize them, to recover from addiction (Dossett, 2013; Valerde \& White-Mair, 1999). To paraphrase AA's core text ("The Big Book,") I was ready to act myself into a new way of thinking, not think myself into a new way of acting (Alcoholics Anonymous World Services, Inc., 2001). 


\section{My participation in a 12-Step Addiction Recovery Program}

So I began my 12-step journey. I worked to abstain from addictive behaviors while redirecting every aspect of my life with each of the 12 steps in mind. These 12 steps of AA are:

1. We admitted we were powerless over alcohol-that our lives had become unmanageable;

2. Came to believe that a Power greater than ourselves could restore us to sanity;

3. Made a decision to turn our will and our lives over to the care of God as we understood Him;

4. Made a searching and fearless moral inventory of ourselves;

5. Admitted to God, to ourselves, and to another human being the exact nature of our wrongs;

6. Were entirely ready to have God remove all these defects of character;

7. Humbly asked Him to remove our shortcomings;

8. Made a list of all persons we had harmed, and became willing to make amends to them all;

9. Made direct amends to such people wherever possible, except when to do so would injure them or others;

10. Continued to take personal inventory and when we were wrong promptly admitted it;

11. Sought through prayer and meditation to improve our conscious contact with God as we understood Him, praying only for knowledge of His will for us and the power to carry that out; and

12. Having had a spiritual awakening as the result of these Steps, we tried to carry this message to alcoholics, and to practice these principles in all our affairs (Alcoholics Anonymous World Services, Inc., 2001, p. $59,60)$.

I came to some powerful realizations about my prior life as I started to work the steps with a sponsor, an addict like me who had worked all the steps. First, I had cultivated beliefs that left me unhappy and incapable of making progress towards my goals. I delineated these beliefs and underlying assumptions as part of my first step work. In my words,

(A)ddiction has been about the following: a feeling of moral, intellectual, and social superiority; withdrawal from others and life based in part on these feelings of superiority; a feeling of not being worthy, especially intellectually and socially; self-pity; anger; always having to be right; the need to control people, places, and events in my life; living small; avoiding risk or uncertainty; not spending money on myself; impatience and intolerance of others' shortcomings; using humor and other techniques to avoid dealing with difficult subjects and/ or talking about myself; indecisiveness; self-centeredness; no real sense of boundaries in relationships; not standing up for myself and stating what I wanted; and an overwhelming feeling of being scattered, unfocused, and out of control socially, intellectually, and professionally (May 28, 2002).

Building on these realizations, I committed in steps 2 and 3 to stop trying to control people and events by turning my thoughts, words, and deeds over to the care of a Higher Power of my understanding. That meant that even as a leader I would no longer be in charge; any efforts to try to control people or events would be futile.

Step 4 asked me to list and analyze my resentments, or feelings of bitterness or anger towards a person, place, institution, or condition. The effort took over a year to complete the first time and consisted of 87 single-spaced pages. Here are two examples of resentments I identified.

Resentment: Gossip

Cause: People not talking about themselves; negative, catty, and petty. Might be talking about me if they're talking about others.

Affects My: Willingness and ability to talk about myself. Focus on the positive and what's right as opposed to what's wrong in others. Being in the present and with people.

Exact nature of my wrong, defect or shortcoming: Wanting to control what others do and fear of what others will think/say about me, about which I also have no control and need not concern myself with. Taking things personally.

Resentment: San Francisco Board of Supervisors

Cause: Support legislation inconsistent with key day to day issues in the city.

They're idealogues. Political correctness matters most.

Affects My: Interest in city affairs and politics. I view them as a lost cause. I remain uneducated and uninvolved.

Exact Nature of My Wrong, Defect, or Shortcoming: Trying to control others. Wanting things my way. Black and white thinking - they're wrong, I'm right (April 10, 2003).

I presented these resentments to my sponsor during 2 four-hour sessions. This effort constituted the fifth step. The most striking conclusion that I drew from this experience was the extent to which anger had dominated my life. I felt foolish realizing how trivial matters had consumed so much of my energy.

I left my sponsor's home exhausted after completing this fifth step. Yet as I approached my car I felt an incredible sense of relief, like 20 pounds had instantaneously been lifted from my body. Countless sources of anger, bitterness, and frustration had been excised. I felt lighter 
and happier. I sensed my worldview was changing for the better.

The next two steps offer a means of identifying and letting go of what blocked me from being useful to others, my Higher Power, and myself (Pittman \& Weber, 1992). My initial effort on step 6 led me to identify 25 character defects, or things in myself I found objectionable (Alcoholics Anonymous World Services, Inc., 2001) that accompanied my addictive behavior. These included waiting for things to happen; wanting things my way; wanting to control things; thinking endlessly and exclusively about the future; self-pity; perfectionism; and having to be right on all occasions. I came to see how these and other defects had (and still have) severe negative consequences.

My defects have kept and continue to keep me alone, isolated, angry, shut down ... and unwilling or unable to engage others. My defects are a black hole for my energy, leading me to become trapped in a spiral of anger, bitterness, and frustration. I end up leading a life that's conservative, safe, and small ... My defects have contributed to a sense of hopelessness ... They've kept me from being present, fully engaged, and available to others and myself. The obsessiveness to which I fall prey blocks out much of the beauty and wonder I've had frequent glimpses of since being in recovery (June 9, 2003).

Recovery taught me that my character defects weren't permanent. By seeking the help of my Higher Power in step 7, I could be freed of them. I could change! I indeed felt less pressure to live life in a certain way as these defects decreased in severity.

Step 8 asked me to acknowledge the individuals and institutions I had wronged during my addiction. I expressed my remorse and, where appropriate, made reparations. For example, here's an amends I made to my wife:

Sweetheart,

I apologize for my:

- $\quad$ Dismissiveness

- Verbal abusiveness

- Moodiness

- Not reaching out to you when I am depressed or about other issues bothering me

- Hiding my addiction

- Criticalness

- Not being supportive

- $\quad$ Not being available

- $\quad$ Not making more money
- $\quad$ Procrastination around earning more money and figuring out what I want to do for a living (including getting a job)

I cannot undo the consequences of these behaviors on you and our relationship. The only true amends I can make is to change these behaviors, which I am committed to doing today, tomorrow, and every day thereafter. I love you very much, and strive to demonstrate that love in my word and deed.

Love,

Mitchell (December 11, 2003)

Step 10 challenged me to conduct a daily personal inventory to recognize what I did well and where I could have done better. In other words, I mined my existence to identify what Denzin (1993) refers as sobriety problems. They include anger, resentment, depression, conflict at home or work, other relationship problems, loneliness, impatience, living too far in the past or future, envy, being fired from a job, and losing one's sobriety, among others. Writing became an indispensible tool in this process (Richardson \& St. Pierre, 2000). Now I often record thoughts, feelings, and emotions that come up during the day, typically in the evening or next morning. This effort allows me to process what I've experienced, reinforce lessons I've learned, make adjustments, and observe change and continuity in my life.

Here's an example of my work on step 10.

Where did I fall short today?

- Saying I didn't want to learn a new software program

- Not being direct with boss about his desire to rearrange my office furniture

- $\quad$ Remaining down in the dumps and not taking contrary action

- Being vague with Karen regarding the effect of Bill's comment on me

- $\quad$ Being sarcastic on Twitter

To whom do I owe an amends?

- My colleagues

- My wife

- Myself

Where was I of service? What good did I do?

- Led session tonight and engaged speaker in question and answer session

- $\quad$ Responded promptly and courteously to emails

- Was supportive of others in meetings 
What am I grateful for?

- People who volunteer as speakers for the program I run

- The university that hosts this program

- Our accountant

- My mother

- My wife

- $\quad$ My house (March 10, 2015)

I committed to pray and meditate in step 11. I have done so regularly for the last 15 years. My connection to a power greater than myself-and the world around me, more importantly, intensified. I felt less alone.

I next turned my energy to step 12. I found its focus on integrating 12 step principles in all areas of my life particularly instructive for transforming my thoughts about leadership. To paraphrase AA literature, "ambition is not what I thought it was ... true ambition is the deep desire to live usefully and walk humbly under the grace of God" (Alcoholics Anonymous, Inc., 1981, p.125).

In short, while completing the 12 steps I was developing an inner observer to reflect on feelings, thoughts, and behaviors. I became more introspective and mindful of how I expressed myself and in turn was perceived by others. My understanding of my emotions and skills in managing them deepened, as did my ability to manage the moods and emotions of others. I felt increasingly connected to my entire self, others, and the world around me. As I gained these perspectives I felt myself gaining in humility. More importantly, I could see the limitations of my old ways of understanding and the internal narrative I had crafted about my life - and was working to revise both (Alcoholics Anonymous World Services, 1981; Carnes, 2012; George, 2000; Mitroff \& Denton, 1999; Tillmann, 2009). To continue this work my challenge was clear: "I need to concentrate not so much on what needs to be changed in the world as on what needs to be changed in me and in my attitudes" (Alcoholics Anonymous World Services, Inc., 1981, p. 417). It was pointless to strive to change others or wait for them to change the world (Barciela, 1998; Carnes, 2012).

\section{The transformation of my per- spectives on leadership}

My perceptions of leadership were transformed by continuing to apply the principles embodied in the 12 steps in all areas of my life, particularly as they were informed by a deeper understanding of leadership theory and practice gained while completing a doctoral program. While I had I once focused on meeting my needs (Friedman, 2016), now I feel myself increasingly opting for service over self-interest. The AA tradition stating, "Our leaders are but trusted servants" has been critical for me in this regard (Alcoholics Anonymous World Services, Inc., 1981, p. 132). In other words, I've felt a growing kinship with servant leadership (Block, 1993). I increasingly relate to this approach as a "way of being" during which I relinquish control to focus on facilitating, empowering, and collaborating with others. I am also better able to consider multiple sides of an issue and varying perspectives. It allows me to realize my commitment to the growth of people based on an understanding of the whole person combined with a commitment to be more open and transparent, as well as a desire to build an inclusive community (Avolio \& Gardner, 2005; Block, 1998; Claar, Jackson, \& TenHaken, 2014; Friedman, 2016; Greenleaf, 1970; Northouse, 2016).

I recall fondly one episode that enabled me to realize the impact of changes I was going through as a leader. In 2005-2006 I served as president of the local chapter of a national professional association. I oversaw bimonthly membership meetings attended by over 100 individuals. I had a high profile at these events, yet was conscious about how I had conducted myself in the past. I was determined to apply my 12-step insight to the experience of leadership.

Our November 2005 meeting proved especially challenging given the program's complexity and larger than expected attendance. I was delighted with how my team of officers attended to every detail and acknowledged them publicly throughout the day. Meanwhile, I facilitated the meeting but otherwise remained behind the scenes to help volunteers and interact with members.

I was on a high as I headed home. After speaking briefly with my wife I retreated to our bedroom to relax before dinner. As I sat quietly I felt a wave of emotion come over me. I began to cry. I continued for five minutes or so, having never before had the experience of shedding tears of joy for this long. It wasn't about me that day, I recognized. I could serve with pride and accomplishment as a leader whose primary aim was to support others in their work. I didn't have to be the expert; my foci turned to ensuring open communications and creating an environment that supported trial and error and consistency between words and actions (Robbins, 1992).

I've also consciously attempted to apply these servant leadership principles to my work as a higher education administrator and faculty member. I've translated them into core commitments I look to for inspiration and share with others. 
1. I consider myself a role model for students in my personal and professional behavior. My goal is to embody the knowledge, skills, and attitudes they need to succeed.

2. I consider students to be co-creators of their educational experience. I view them as peers and vest in them the responsibility for their successes. At the same time I recognize that being in school, especially as an adult, poses special challenges. I welcome these challenges as opportunities to proactively help students throughout their educational journey.

3. I respond to student communication promptly, and am readily available to help whenever, wherever, and however I can.

4. I urge students to seek me out if I can help, particularly if they are at a loss for where to find a solution to a problem they encounter when navigating the complex and often perplexing bureaucracies of modern higher educational institutions. My formal job description has never limited me in this respect. I recognize that no task is too small and the proclamation that "it is not my job" is unacceptable when working with students.

5. I am available to students after they have graduated for assistance with any matter where they believe I might be able to help.

6. I strive to meet students where they are in terms of individual personal, academic, and professional development-not where I am in those areas. I recognize that my personal history and professional paths are mine alone, and that each student needs to define success on his or her own terms.

7. I relentlessly pursue a program of personal and professional self-development. I need to grow as an individual to better serve my students and other stakeholders in higher education.

8. I strive to be humble and authentic. I aim to be direct and consistent in how I interact with people. Still, I am far from perfect. I make mistakes. I promptly admit when I am wrong and apologize. I aim to learn from each mistake so my future actions are more consistent with the kind of person I aspire to be.

9. I accept total responsibility for how and what I communicate. At the same time, I recognize that I need to continue to improve my written and oral skills as an integral component of my growth as a leader.

10. I consider every interaction with students as a teaching and learning opportunity for all parties (Friedman, 2016, p. 114-115).
I feel these commitments epitomize the kind of leader I am continually in the process of becoming as a result of my participation in a 12-step program.

My 12-step program work also led me to reevaluate my role as a follower (Friedman, 2016). I had seen followership as a secondary position reserved for the weak, docile, conformists, and failures. Furthermore, I considered being a follower as a temporary resting place until I became a leader (Chaleff, 2009; Uhl-Bien, Riggio, Lowe, \& Carsten, 2014). I waited impatiently until the powers that be realized a superstar like me merited a greater role, where my impressive intellect and ability would trump all other perspectives. If anything, I was an alienated, passive follower who on occasion would adopt a pragmatic stance towards leaders who necessarily would tend to my specific needs much like a family would (Bion, 1961; Kelley, 2008).

I gradually came to realize there was a continuum of followership that moved from passivity to blind agreement to co-constructing leadership (Billot, et al., 2013). Concurrently, as I cultivated the spiritual component of my life while working the 12-steps of recovery, many amazing things happened that were critical for how I embraced followership. I became more self-aware and increasingly likely to assume responsibility for the organization and myself. I was proactive in my personal development; more focused on building rich relationships with others; and more likely to go beyond my formal job description to help the organization. I experienced a reduction of my ego and when appropriate challenged leaders by offering constructive feedback, while knowing when to take different stands on issues. I also worked to support the rest of the team and the leader and exceeded my job's requirements (Banutu-Gomez, 2004; Chaleff, 2009; Cunha et al., 2013; Friedman, 2016).

Finally, I've increasingly internalized the reciprocal relationship between followership and leadership. That is, followers share a common purpose with leaders and want them and organization to succeed. They do by in framing their role as being "upward leadership" (Carsten, Uhl-Bien, West, Patera, \& McGregor, 2010; Chaleff, 2009). I've observed in academia how an individual may be a follower and leader at different times; the roles are complex, shifting, and must be enthusiastically embraced (Billot et al., 2013; Cox, Plagens, \& Sylla, 2010). My continued recognition of fluidity in followership and leadership roles thus seems critical to my future work in higher education (Friedman, 2016). 


\section{The bottom line}

I don't want to leave the impression that changes in my leadership and followership are complete. It's about progress rather than perfection (Alcoholics Anonymous World Services, Inc. (2001). I retain vestiges of a skeptical, critical, and disdainful attitude. I can come across as abrupt and dismissive. I occasionally struggle when working with leaders I consider slower and less capable. I know intellectually that these leaders need and get strength from followers like me, yet I resist (Chaleff, 2009). The 12 steps have enabled me to focus on a broader purpose to serve and thus put myself in a position to be a model for others.

I also at times struggle with anger and resentment, taking things personally, and people, situations, and places not to my liking. The 12 steps, along with the support of my sponsor and program friends, continue to provide an invaluable touchstone as I grapple with these situations while striving to maintain continued sobriety.

\section{Conclusion}

I've extended what I've learned while participating in a 12-step program based on the principles and traditions of AA to my life outside recovery. Sobriety from compulsive behavior is paramount; that said, my real recovery lay in how I've become a better person, leader, and follower. I believe had I not worked the 12-steps my addiction only would have become worse. In short, my life-and practice of leadership and followership-would not be what it is today without that experience. Transforming my attitude and behavior made possible everything else-my completion of a doctoral program, ability to navigate professional and personal challenges, and confidently serve and follow others. Indeed, my recovery work stands out even more strongly as a leadership formative experience as I continue to reflect on it.

I believe many fellow addicts can relate to my story. Individuals without the recovery experience may not grasp the particulars, yet I nonetheless feel that the effort to look at my life by embracing a spiritual solution has universal appeal. I imagine that many individuals would benefit from similar introspection and the potential that prior experience has for shaping their leadership development. As the faces of leadership change along with the demands imposed by our evolving world, I believe that there's latent potential for leadership development in a range of previously unexplored experiences. Leaders and followers of the future need be cognizant of the possibilities in their life stories as they attempt to grapple with challenges in their organizations.

\section{References}

[1] Alcoholics Anonymous World Services, Inc. (2001). Alcoholics Anonymous (4th edition). New York: Alcoholics Anonymous World Services, Inc

[2] Alcoholics Anonymous World Services, Inc. (1981). Twelve Steps and Twelve Traditions. New York: Alcoholics Anonymous World Services, Inc

[3] Avolio, B. J., \& Gardner, W. L. (2005). Authentic leadership development: Getting to the root of positive forms of leadership. The leadership quarterly, 16(3), 315-338

[4] Banutu-Gomez, M.B. (2004). Great leaders teach exemplary followership and serve as servant leaders. Journal of American Academy of Business, 4(1/2), 143-151

[5] Barciela, S. (1998). Dharamshala dreaming: A traveler's search for the meaning of work. From Spears, L.C. (Ed.), Insights on leadership. New York: John Wiley \& Sons

[6] Bennis, W.G., \& Thomas, R.J. (2002). Geeks \& geezers: How era, values, and defining moments shape leaders. Boston: Harvard Business School Press

[7] Billot, J., West, D., Khong, L., Skorobohacz, C., Roxå, T., Murray, S., \& Gayle, B. (2013). Followership in higher education: Academic teachers and their formal leaders. Teaching and Learning Inquiry: The ISSOTL Journal, 1(2), 91-103

[8] Bion, W. R. (1961). Experiences in groups: And other papers. New York: Routledge

[9] Block, P. (1993). Stewardship: Choosing service over self interest. San Francisco: Berrett-Koehler Publishers

[10] Block, P. (1998). From leadership to citizenship. In Spears, L. C. (1998). Insights on leadership: Service, stewardship, spirit, and servant-leadership. John Wiley \& Sons

[11] Carnes, P. (2012). A gentle path through the twelve steps: The classic guide for all people in the process of recovery. Center City, Minnesota: Hazelden Publishing

[12] Carsten, M. K., Uhl-Bien, M., West, B. J., Patera, J. L., \& McGregor, R. (2010). Exploring social constructions of followership: A qualitative study. The Leadership Quarterly, 21(3), 543-562

[13] Chaleff, I. (2009). The courageous follower: Standing up to \& for our leaders. San Francisco: Berrett-Koehler Publishers

[14] Claar, V. V., Jackson, L. L., \& TenHaken, V. R. (2014). Are Servant Leaders Born or Made? Servant Leadership, 46

[15] Cox, R. W., Plagens, G. K., \& Sylla, K. (2010). The Leadershipfollowership dynamic: Making the choice to follow. International Journal of Interdisciplinary Social Sciences, 5(8)

[16] Cunha, M. P., Rego, A., Clegg, S., \& Neves, P. (2013). The case for transcendent followership. Leadership, 9(1), 87-106

[17] Denzin, N. K. (1993). The alcoholic society: Addiction and recovery of the self. Piscataway, NJ: Transaction Publishers

[18] Dossett, W. (2013). Addiction, spirituality and 12-step programmes. International Social Work, 56(3), 369-383 
[19] Ellis, C., Adams, T. E., \& Bochner, A. P. (2011). Autoethnography: an overview. Historical Social Research/Historische Sozialforschung, 273-290

[20] emerald, E., \& Carpenter, L. (2016). "Autoethnography: Is my own story narrative research?” From Dwyer, R., Davis, I., \& emerald, e., Narrative research in practice: Stories from the field. Singapore: Springer

[21] Friedman, M. (2016). My evolution as a higher education leader and follower. In Mitchell, P., \& Ramirez, S. (Eds.). Lessons in leadership: Tips for an emerging P-20 leader in the 2 lst century. Los Gatos, CA: Robertson Publishing

[22] George, J. M. (2000). Emotions and leadership: The role of emotional intelligence. Human relations, 53(8), 1027-1055

[23] Greenleaf, R. (1970). The servant as leader. From Spears, L.C. (Ed.), Insights on Leadership. New York: John Wiley \& Sons

[24] Groves, D. H. (1972). Charismatic leadership in Alcoholics Anonymous. A case study. Quarterly journal of studies on alcohol, 33(3), 684-691

[25] Hughes, R. L., Ginnett, R. C., \& Curphy, G. J. (2006). Leadership: Enhancing the lessons of experience (5th ed.). New York: McGraw-Hill/Irwin

[26] Janson, A., Popper, M., Blyde, P., Markwick, L., \& Ranatunga, C. (2008). Extracting leadership knowledge from formative experiences. Leadership, (4)1, 73-94. doi: $10.1177 / 1742715007085770$

[27] Kaskutas, L.A., Borkman, T., Laudet, A., Ritter, L.A., Witbrodt, J., Subbaraman, M., \& Bond, J. (2014). Elements that define recovery: The experiential perspective. Journal of Studies on Alcohol and Drugs. 75(6), 999-1010

[28] Kelley, R. E. (1992). The power of followership. New York: Currency Doubleday

[29] Kelley, R. E. (2008). Rethinking followership. From Riggio, R. E., Chaleff, I., \& Lipman-Blumen, J. (Eds.). (2008). The art of followership: How great followers create great leaders and organizations (Vol. 146). New York: John Wiley \& Sons, 5-16

[30] Kempster, S. (2007). "Echoes from the past”: An exploration of the impact of "notable people" on leadership learning. In Academy of Management Annual Meeting Proceedings (1-6). Academy of Management. Retrieved from http://0-search. ebscohost.com.ignacio.usfca.edu/login.aspx?direct $=$ true $\& d b=$ bth $\& A N=26536349 \&$ site $=$ eds-live $\&$ scope $=$ site

[31] Kouzes, J.M. (1998). Finding your voice. From Spears, L.C. (Ed.), Insights on leadership. New York: John Wiley \& Sons

[32] Maister, D., Green, C.H., \& Galford, R.M. (2000). The trusted advisor. New York: The Free Press

[33] McShane, S.L., \& Von Glinow, M. (2013). Organizational behavior (6th ed.). New York: McGraw-Hill Irwin

[34] Mitroff, I. I., \& Denton, E. A. (1999). A study of spirituality in the workplace. MIT Sloan Management Review, 40(4), 83-92

[35] Northouse, P. G. (2016). Leadership: Theory and practice (7th edition). Thousand Oaks, California: Sage Publications

[36] Pittman, P., \& Weber, T. (1992). Drop the rock: Removing character defects. Center City, Minnesota: Hazelden Publishing \& Educational Services.

[37] Richardson, R., \& St. Pierre, E.A. (2000). Writing: A method of inquiry. From Denzin, N.K. \& Lincoln, Y.S. (Eds.). Handbook of Qualitative Research (2nd edition). Thousand Oaks, CA: Sage Publications
[38] Robbins, L. (1992). Designing more functional organizations: the 12 step model. Journal of Organizational Change Management, 5(4), 41-58

[39] Schutte, N. S., Malouff, J. M., Hall, L. E., Haggerty, D. J., Cooper, J. T., Golden, C. J., \& Dornheim, L. (1998). Development and validation of a measure of emotional intelligence. Personality and individual differences, 25(2), 167-177

[40] Shamir, B., \& Eilam, G. (2005). "What's your story?" A life-stories approach to authentic leadership development. The Leadership Quarterly, 16, 395-417

[41] Sparrowe, R.T. (2005). Authentic leadership and the narrative self. The Leadership Quarterly, 16, 419-439

[42] Tillmann, Lisa M. (2009). Body and bulimia revisited: Reflections on "A Secret Life." Journal of Applied Communication Research, 37(1), 98-112

[43] Uhl-Bien, M., Riggio, R. E., Lowe, K. B., \& Carsten, M. K. (2014). Followership theory: A review and research agenda. The Leadership Quarterly, 25(1), 83-104

[44] Valverde, M., \& White-Mair, K. (1999). 'One day at a time' and other slogans for everyday life: the ethical practices of alcoholics anonymous. Sociology, 33(2), 393-410

[45] White Jr., R. D. (2010). The micromanagement disease: Symptoms, diagnosis, and cure. Public Personnel Management, 39(1), 71-76

[46] Whiteside, K. (2013). Identifying the impact of 12-step programs on executives' leadership styles. Unpublished master's thesis. Pepperdine University

\section{Appendum to Article 3}

The quote on crucibles (2002, pg. 400 reprinted with permission. From „Geeks and Geezers: How Era, Values, and Defining Moments Shape Leaders“ by Warren G. Bennis and Robert J. Thomas. Harvard Business Press Books, 2002.

The Twelve Steps are reprinted with permission of Alcoholics Anonymous World Services, Inc. (“A.A.W.S.”) Permission to reprint the Twelve Steps does not mean that A.A.W.S. has reviewed or approved the contents of this publication, or that A.A. necessarily agrees with the views expressed herein. A.A. is a program of recovery from alcoholism only - use of the Twelve Steps in connection with programs and activities which are patterned after A.A., but which address other problems, or in any other nonA.A., does not imply otherwise.

The 10 core commitments (pg. 45 of article) are reprinted with permission of Patricia Mitchell, co-editor of Lessons in leadership: Tips for an emerging P-20 leader in the 2lst century. Los Gatos, CA: Robertson Publishing, 2016. 